\title{
Polyphenol Oxidase Activity and Colour Changes of 'Starking' Apple Cubes Coated with Alginate and Dehydrated with Air
}

\author{
Susana Daniela Sousa Fernandes, Catarina Araújo da Silva Ribeiro, Maria Filomena de Jesus Raposo, \\ Rui Manuel Santos Costa de Morais, Alcina Maria Miranda Bernardo de Morais
}

CBQF/Escola Superior de Biotecnologia da Universidade Católica Portuguesa, Rua Dr. António Bernardino de Almeida, Porto, Portugal.

Email: abmorais@esb.ucp.pt

Received April $1^{\text {st }}, 2011$; revised May 11 ${ }^{\text {th }}, 2011$; accepted May $18^{\text {th }}, 2011$.

\begin{abstract}
The objective was to study the effect of alginate coating on polyphenol oxidase (PPO) activity and colour of 'Starking' apple cubes during dehydration with hot air. Apple cubes were dehydrated at $20^{\circ} \mathrm{C}, 35^{\circ} \mathrm{C}$ or $40^{\circ} \mathrm{C}$, with a parallel airflow. Analysis of PPO activity, colour $\left(L^{*}, a^{*}, b^{*}\right)$ and dry matter were performed along the dehydration process at each temperature. All samples presented a peak in relative PPO activity in the beginning of the drying. Exponential models fitted well the experimental data after the peak. Cubes without coating presented lower PPO activity, suggesting lower browning than coated samples throughout the dehydration process, for all temperatures. Better results for coated samples were obtained with a perpendicular airflow drying at $40^{\circ} \mathrm{C}$, after dipping the whole apple in water at $60^{\circ} \mathrm{C}$ for 10 minutes. In order to prevent coated samples from browning, drying by perpendicular airflow preceded by a thermal treatment of the whole apple is required.
\end{abstract}

Keywords: Alginate Coating, Apple Cubes, Colour, Hot Air Drying, Polyphenol Oxidase

\section{Introduction}

Polyphenol oxidase is an enzyme that, in the presence of oxygen, promotes oxidation of phenolic compounds to quinones [1] in fresh-cut plant tissues, giving their tissues a typical brownish colour due to the formation of insoluble brown pigments (melanin) [2].This chemical reaction can be a drawback for Food Industry, but might be overcome with the application of an edible coating.

An edible coating is a chemical solution that can be somewhat viscous; when applied to the food surface turns into a film, formed by polymers that give some protection to the food product by providing a modified atmosphere, retarding gas transfer, reducing moisture and aroma loss, delaying color changes and improving general appearance during storage [3]. Therefore, the use of these coating films presents evident advantages. Besides being good gas barriers [3], they give a nice brilliant surface to food products, a characteristic appreciated by consumers [4]. Other functional properties of these coatings include carrying gases and solutes, and retaining aromatic compounds. Edible coatings can also incorpo- rate food additives, such as nutrients and antibiotic agents [3,5].

Alginates are polymers most used as coating agents. Bico et al. [6], for example, tested alginate to retard softening and browning of fresh-cut banana, and RojasGräu et al. [7], Khin et al. [8] and Olivas et al. [9] reported the influence of coating on the quality of fresh-cut or minimally processed apples.

The application of alginates as coating material is based on three characteristics, the main one being the capacity of increasing viscosity of the chemical solutions. The second characteristic is their ability to easily form gels when mixing sodium alginate with calcium salts; these gels do not melt when heated. The third characteristic is associated with their capacity to form coating films of sodium alginate [10]. The antioxidant ability of alginate films has been reported in literature [11,12].

Drying is a technique used to preserve foods, as microorganisms can be deactivated and enzymatic/chemical reactions are slowed down, while water activity $\left(a_{w}\right)$ decreases. 
Several studies on the application of edible coatings to fresh apple have already been published $[9,13]$. However, the application of coatings can, sometimes, reduce the firmness [5], due to the low $\mathrm{pH}$ of the film, which can induce an acid hydrolysis of the pectic acid [14]. But there is scarce information on dehydration of fresh-cut coated fruits: Lenart and Piotrowski [15] studied the effect of several coatings (maltodextrin, pectin and others) on physical properties, such as water activity, density and shrinkage of fruits dried by convective drying; Khin et al. $[8,16]$ used sodium alginate as coating material for apple and potato cubes, but dried the samples by osmotic processes. None of these authors studied PPO activity.

The objective of this work was to study the effect of alginate coating on polyphenol oxidase (PPO) activity and colour of 'Starking' apple cubes during dehydration with hot air.

\section{Materials and Methods}

\subsection{Plant Materials}

'Starking' apples were obtained directly from a producer (Frutas Assunção) of Lamego Region (in the North of Portugal). Fruits that did not present any physical or microbial visible injury were stored in the Plant Biotechnology and Postharvest Laboratory, at $4^{\circ} \mathrm{C}$ and $54 \%$ of relative humidity.

\subsection{Sample Preparation}

Apples of identical dimension were washed with running water, cut into halves with a sharp knife, peeled and sliced in cubes $(1.5 \mathrm{~cm}$ thickness) with a template. Half of the cubes were used as control samples, and the other half were dipped in the edible coating solution (alginate) during one minute.

\subsection{Preparation of Edible Coating}

Alginate coating was prepared according to Rojas-Graü et al. [13]. Two grams of sodium alginate $\left(\mathrm{NaC}_{6} \mathrm{H}_{7} \mathrm{O}_{6}\right.$, $\mathrm{BDH}$, Poole, England) were dissolved in $100 \mathrm{ml}$ sterilized distilled water and heated at $70^{\circ} \mathrm{C}$, until the solution became clear. After cooling, glycerol $\left(\mathrm{C}_{3} \mathrm{H}_{5}(\mathrm{OH})_{3}, 85 \%\right.$ purity, Merck, Darmstadt, Germany) was added as plasticizer to a final concentration of $1.5 \mathrm{~g} / 100 \mathrm{ml}$ solution. The solution was emulsified with sunflower oil $(0.025$ $\mathrm{g} / 100 \mathrm{ml}$ coating solution) at $24500 \mathrm{rpm}$ for 5 minutes, before $\mathrm{pH}$ adjustment to 5.6 by using $50 \%(\mathrm{w} / \mathrm{v})$ citric acid $\left(\mathrm{H}_{3} \mathrm{C}_{6} \mathrm{H}_{5} \mathrm{O}_{7}\right.$, Sigma Co., St. Louis, MO, USA).

\subsection{Drying Experiments}

In a first experiment, coated and uncoated samples were dried simultaneously in two trays, at $20^{\circ} \mathrm{C}, 35^{\circ} \mathrm{C}$ or $40^{\circ} \mathrm{C}$ with air at speed of approximately $1 \mathrm{~m} / \mathrm{s}$ and relative humidity of $20 \%$, in a tray dryer with parallel air flow (Armfield, Technical Education, Ringwood Hampshire, UK).

In the second experiment, whole apples were dipped in water at $60^{\circ} \mathrm{C}$ for 10 minutes, afterwards were cut into cubes and coated in alginate, and dried at $40^{\circ} \mathrm{C}$ in the tray dryer, or in a fluidised bed dryer (Armfield, Technical Education, Ringwood Hampshire, UK) with perpendicular air flow at speed of approximately $1 \mathrm{~m} / \mathrm{s}$.

\subsection{Quality Evaluation}

\subsubsection{Colour}

Colour on two different sides of each cube was measured with a hand-held tristimulus reflectance colorimeter (Minolta CR-300, Minolta Corporation, Ramsey, NJ) in the CIE L* a* b* mode CIE Lab colour space [17].

Five cubes per replicate, with and without coating, were used and read on two points. Samples were analysed every hour, during the first five-hours period of the drying process, and after 24h, at the end of the drying.

Five apple cubes from each replicate were placed into a previously weighed Petri dish and were dried inside an incubator (Binder, WTB), at $105^{\circ} \mathrm{C}$, for $24 \mathrm{~h}$. After drying, Petri dish was put in a desiccator to cool to room temperature. Weight was registered before and after drying, using an analytical balances (Sartorius BP 210 S, Germany). Dry matter was calculated according to the equation:

$$
\text { Dry matter }(\%)=\frac{w_{f}}{w_{i}} * 100
$$

$w_{i}$ and $w_{f}$ being the weight of the sample before and after drying.

\subsubsection{Polyphenol Oxidase (PPO) Activity}

PPO activity was determined according to Rocha and Morais [18]. In an external ice bath, $10 \mathrm{~g}$ of fruit per replicate was homogenized with $30 \mathrm{ml} 0.2 \mathrm{M}$ phosphate buffer ( $\mathrm{pH}$ 6.5) and $0.6 \mathrm{~g}$ polyvinylpolypirrolidone (PVPP, Sigma P6755-Germany) during three minutes with one minute interval after each minute. Two drops of Triton X-100 solution (Fluka Biochemika, Switzerland) were added to the solution before the last minute of homogenization. A kitchen magic wand (Braun, MR 6500 $\mathrm{M}$, Poland) and an Ultra-Turrax homogenizer (IKA Labortecknik, T25 Basic, Germany) were used in order to homogenize apple tissue. The mixture was centrifuged (Sorvall RC-5C Instruments, Dupont) at $10000 \mathrm{rpm}$ and $4^{\circ} \mathrm{C}$ for 30 minutes. After centrifugation, mixture was filtered through eight layers of gauze, to a graduated cylinder, and the volume of the centrifugate was recorded. An aliquot $(0.10 \mathrm{ml})$ of the centrifugate was added to the 
$2.80 \mathrm{ml}$ substrate solution (catechol $0.16 \mathrm{M}$ ) just before the assay, and the rate of increase in absorbance at 420 $\mathrm{nm}$ was monitored during $60 \mathrm{~s}$, by using the Shimadzu (UV-1601, Germany) spectrophotometer. The substrate solution $(2.90 \mathrm{ml})$ was used as a reference blank. The linear section on of the activity curve as a function of time was used to determine the enzyme activity $\left(\mathrm{U} \cdot \mathrm{g}^{-1}\right.$. $\mathrm{FW} \cdot \mathrm{min}^{-1}$ ), as the Equation (2).

All determinations were performed in triplicate.

The relative PPO activity was calculated according to the Equation (3), where DM0 and DM are the dry matter of the fresh apple and of the dried sample respectively.

\subsection{Statistical Analysis}

Statistica 6.0 (ANOVA/MANOVA) (Stat Soft Inc., 1984-2001) was used for the analysis of data. The overall Least Significance Difference (post-hoc Fisher LSD test; $p<0.05$ ) was calculated and used to detect significant differences among temperatures.

\section{Results and Discussion}

Cutting of fruits or vegetables can cause the disruption of tissues, enzymes and substrates, usually sequestered within the vacuoles, become mixed with other compounds in the cytoplasm. These physiological changes are usually accompanied by vitamin loss, discoloration or browning of tissues, softening and shorter storage-life.

Enzymatic browning caused by polyphenol oxidase can be evaluated by determining enzymatic activity. Thus, an increase of enzymatic activity would suggest an increase of browning/darkening caused by the enzyme.

In the first experiment, all curves of relative PPO activity presented a peak at the beginning of the dehydration process of the apple cubes, with $14 \%$ to $17 \%$ dry matter (Figure 1). This might be justified by a denovo synthesis of PPO induced by the cutting of the vegetal tissue during the preparation of the samples [19]. Rocha et al. [20] reported a similar behaviour in peeled carrot. Afterwards, the relative enzymatic activity decreased until the end of the dehydration process, for all temperatures tested.

Coated apple cubes presented values of relative enzymatic activity higher than those for uncoated samples, for all temperatures (Figure 1). The application of the coating was not effective in protecting from oxidation during

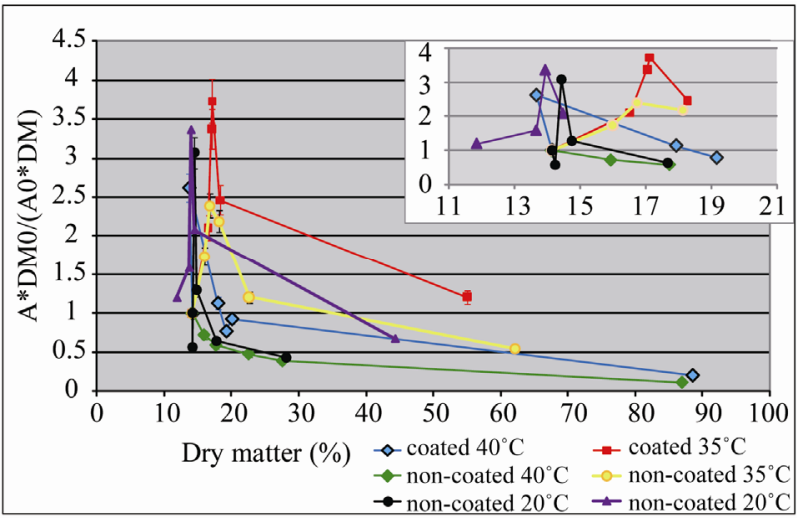

Figure 1. Relative activity of polyphenol oxidase (A*DM0/ (A0*DM)) of 'Starking' apple cubes, coated and non-coated, dried with parallel airflow at $20^{\circ} \mathrm{C}, 35^{\circ} \mathrm{C}$ and $40^{\circ} \mathrm{C}$; DM and $\mathrm{A}$, and DMO and AO are dry matter (\%) and PPO activity $\left(\mathrm{U} \cdot \mathrm{g}^{-1} \cdot \mathrm{FW} \cdot \mathrm{min}^{-1}\right)$ of dried sample and fresh apple, respectively. Results between 10 and $20 \%$ DM are expanded in the smaller graphic.

the dehydration process, because it might induce a higher water activity, by entrapment of moisture in the interior of coated apple cubes, than in non-coated samples, and enzymatic activity is higher for higher water activity [21]. These results can also be related with the $\mathrm{pH}$ of the coating solution, 5.6. In spite of presenting higher activity at pH 6.5 - 7.0 [22-25], PPO is still active at pH 5.5 - 6.0, in litchi extracts [25] and papaya extracts [22].

Furthermore, the coating might decrease the drying rate, thus maintain the humidity at the surface at higher levels in relation to uncoated samples. PPO relative activity was lower for non-coated cubes dried at $40^{\circ} \mathrm{C}$ and $20^{\circ} \mathrm{C}$. On the other hand, higher values for relative enzymatic activity were obtained in coated samples that were dried at $35^{\circ} \mathrm{C}$. These results may be understood, taking into account that the optimal temperature for PPO activity in apples is around $30^{\circ} \mathrm{C}$ [23]: PPO activity was higher at $35^{\circ} \mathrm{C}$, which is near the optimal temperature; and it was lower at $20^{\circ} \mathrm{C}$ and $40^{\circ} \mathrm{C}$. Eidhin et al. [23] also reported a lower PPO activity (around $50 \%$ ) for $20^{\circ} \mathrm{C}$ and $40^{\circ} \mathrm{C}$.

The values of the PPO activity after the peak were adjusted to exponentials (Figure 2). The equations fitted reasonably well the experimental data, the correlation coefficient being higher than 0.80 (this one for the noncoated samples dried at $20^{\circ} \mathrm{C}$ ). The inactivation of $\mathrm{PPO}$

$$
\begin{aligned}
\mathrm{PPO}-\mathrm{A} & =\frac{\text { slope }(\mathrm{Abs} / \mathrm{sec}) * \text { extract }(\mathrm{ml}) * 60(\mathrm{sec} / \mathrm{min})}{0.001(\mathrm{AbsU}) * \text { sample vol.cell }(\mathrm{ml}) * \text { sample weight }(\mathrm{g})} \\
\mathrm{PPO}-\mathrm{RA} & =\frac{\mathrm{PPO}\left(\mathrm{U} \cdot \mathrm{g}^{-1} \cdot \mathrm{FW} \cdot \mathrm{min}^{-1}\right) * \mathrm{DM} 0(\%)}{\mathrm{PPO} \text { activity of fresh apple }\left(\mathrm{U} \cdot \mathrm{g}^{-1} \cdot \mathrm{FW} \cdot \mathrm{min}^{-1}\right) * \mathrm{DM}(\%)}
\end{aligned}
$$




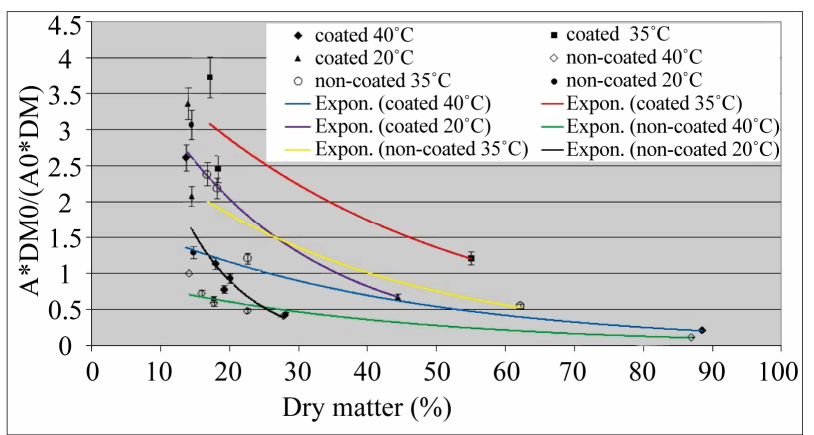

Figure 2. Exponential curves fitting the Relative activity of polyphenol oxidase (A*DM0/(A0*DM)) of 'Starking' apple cubes, coated and non-coated, dried with parallel airflow at $20^{\circ} \mathrm{C}, 35^{\circ} \mathrm{C}$ and $40^{\circ} \mathrm{C}$ after the initial peak; DM and $A$, and DMO and A0 are dry matter (\%) and PPO activity $\left(\mathrm{U} \cdot \mathrm{g}^{-1}\right.$. $\mathrm{FW} \cdot \mathrm{min}^{-1}$ ) of dried sample and fresh apple, respectively.

at $20^{\circ} \mathrm{C}$, when the dry matter content increased, was higher than at other temperatures, specially for noncoated samples: this is reflected in the constant of the exponential, which is -0.1077 for non-coated samples dried at $20^{\circ} \mathrm{C}$ (Equation (9)); for other temperatures this constant is around -0.03 (Equations (4)-(7), Table 1).

Values of luminosity were in accordance with relative PPO activity results: $L^{*}$ values were lower for coated samples with intermediate moisture content (dry matter around $55 \%$ ) dried at $35^{\circ} \mathrm{C}$ (Figure 3). No significant difference was detected among other samples, except for a tendency of non-coated samples dried at $40^{\circ} \mathrm{C}$ to present higher $\mathrm{L}^{*}$ values towards the end of the process (high dry matter).

Table 1. Models to fit experimental data on relative activity of polyphenol oxidase (RA $=A * D M 0 /(A 0 * D M))$ of 'Starking' apple cubes, coated and non-coated, dried with parallel airflow at $20^{\circ} \mathrm{C}, 35^{\circ} \mathrm{C}$ and $40^{\circ} \mathrm{C}$, after the peak at the beginning of the drying.

\begin{tabular}{lcc}
\hline Sample & \multicolumn{1}{c}{ Model } & R \\
\hline $\begin{array}{l}\text { Coated, } \\
\text { dried at } 40^{\circ} \mathrm{C}\end{array}$ & $\mathrm{RA}=1.9283^{*} \exp (-0.0256 * \mathrm{DM})(\mathbf{4})$ & 0.89 \\
$\begin{array}{l}\text { Non-coated, } \\
\text { dried at } 40^{\circ} \mathrm{C}\end{array}$ & $\mathrm{RA}=1.0195 * \exp (-0.0263 * \mathrm{DM})(5)$ & 0.96 \\
$\begin{array}{l}\text { Coated, } \\
\text { dried at } 35^{\circ} \mathrm{C}\end{array}$ & $\mathrm{RA}=4.7216^{*} \exp (-0.0249 * \mathrm{DM})(\mathbf{6})$ & 0.94 \\
$\begin{array}{l}\text { Non-coated, } \\
\text { dried at } 35^{\circ} \mathrm{C}\end{array}$ & $\mathrm{RA}=3.3034^{*} \exp (-0.0296 * \mathrm{DM})(7)$ & 0.94 \\
$\begin{array}{l}\text { Coated, } \\
\text { dried at } 20^{\circ} \mathrm{C}\end{array}$ & $\mathrm{RA}=5.0745^{*} \exp (-0.0456 * \mathrm{DM})(\mathbf{8})$ & 0.96 \\
$\begin{array}{l}\text { Non-coated, } \\
\text { dried at } 20^{\circ} \mathrm{C}\end{array}$ & $\mathrm{RA}=7.7192 * \exp (-0.1077 * \mathrm{DM})(\mathbf{9})$ & 0.80 \\
\hline $\begin{array}{l}\text { DM, A, DM0 and A0 are dry matter }(\%) \text { and PPO activity }\left(\mathrm{U} \cdot \mathrm{g}^{-1} \cdot \mathrm{FW} \cdot \mathrm{min}^{-1}\right) \\
\text { of dried sample and fresh apple, respectively. Numbers of equations are } \\
\text { indicated in (n). }\end{array}$ &
\end{tabular}

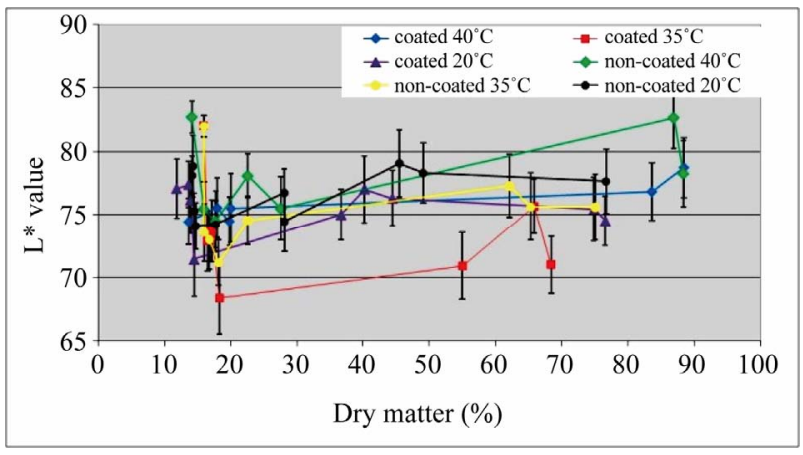

Figure 3. $\mathrm{L}^{*}$ values of 'Starking' apple cubes, coated and non-coated, dried with parallel airflow at $20^{\circ} \mathrm{C}, 35^{\circ} \mathrm{C}$ and $40^{\circ} \mathrm{C}$.

With respect to $b^{*}$ values, no differences were detected between samples (Figure 4). As $a^{*}$ values (results not shown) were low, chroma values were near $b^{*}$ values, therefore, results are not presented. Visually, all samples presented an acceptable colour. Emam-Djomeh et al. [26] obtained a good visual appearance of semirings of apple coated with carboxymethyl cellulose prior to osmotic dehydration.

In order to reduce browning of the dried coated samples, a thermal treatment of the whole apples was performed by dipping in hot water at $60^{\circ} \mathrm{C}$, during $10 \mathrm{~min}$ utes. According to Damaldi et al. [27], dipping whole strawberries, during 10 minutes, in water at $50^{\circ} \mathrm{C}$ reduced enzymatic activity by $44 \%$, and the enzyme was completely destroyed at $65^{\circ} \mathrm{C}$. Kim et al. [28] had also found that slices of some apple varieties thermally treated at $45^{\circ} \mathrm{C}$, during 105 minutes, did not show browning after treatment and preserved firmness better.

In addition, the dehydration process was also performed in a dryer with perpendicular airflow, with the aim of speeding the drying. In fact, the relative PPO activity decreased (Figure 5) in relation to the dehydration at $40^{\circ} \mathrm{C}$ with no previous thermal treatment (Figure 1).

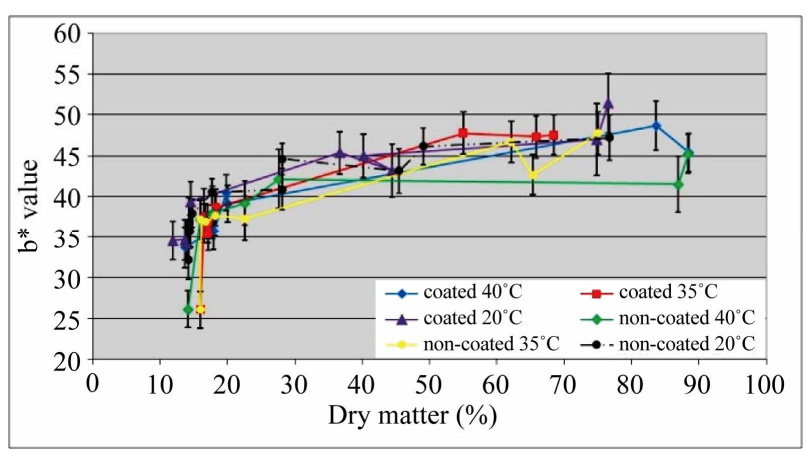

Figure 4. $b^{*}$ values of 'Starking' apple cubes, coated and non-coated, dried with parallel airflow at $20^{\circ} \mathrm{C}, 35^{\circ} \mathrm{C}$ and $40^{\circ} \mathrm{C}$. 


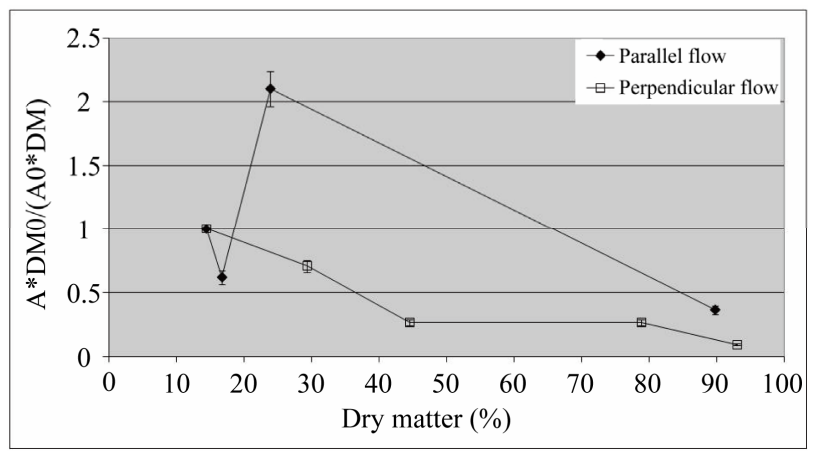

Figure 5. Relative activity of polyphenol oxidase (A*DM0/ (A0*DM)) of coated 'Starking' apple cubes dried with parallel airflow or perpendicular airflow at $40^{\circ} \mathrm{C}$; DM and $\mathrm{A}$, and DMO and AO are dry matter (\%) and PPO activity $\left(\mathrm{U} \cdot \mathrm{g}^{-1} \cdot \mathrm{FW} \cdot \mathrm{min}^{-1}\right)$ of dried sample and fresh apple, respectively.

The perpendicular airflow reduced relative activity of the enzyme even further, although the values for the two types of airflow came closer for high dry matter contents (more than 90\%). This may be due to the fact that the perpendicular airflow drying is faster than the parallel airflow drying. This result suggests that the drying rate may be more important than the coating, overcoming the range of water activity values for which PPO activity would be higher.

With respect to colour changes, the $\mathrm{L}^{*}$ value was higher for parallel airflow drying, towards the end of the dehydration process (Figure 6).

No differences were detected between $b^{*}$ values of samples dried by both types of drying (Figure 7). Visually, the coated cubes dried with perpendicular airflow presented a better aspect (apparently, less browning), which was not in agreement with the luminosity results.

\section{Conclusions}

The coating was not effective in controlling polyphenol

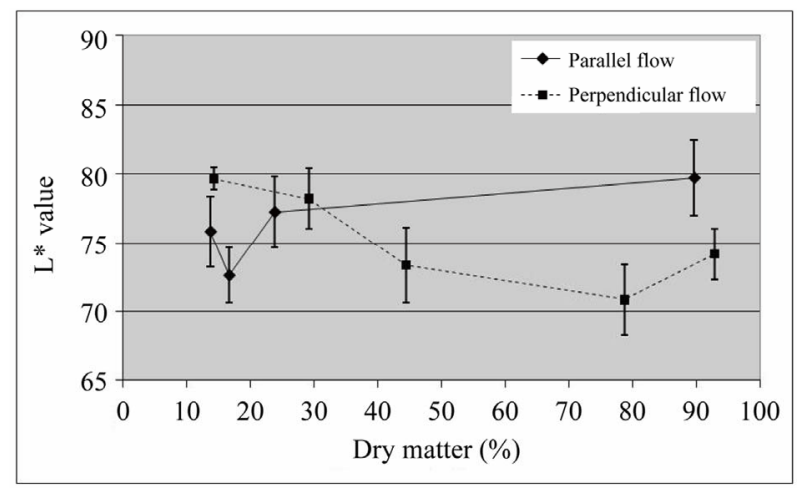

Figure 6. $\mathrm{L}^{*}$ values of coated 'Starking' apple cubes dried with parallel airflow or perpendicular airflow at $40^{\circ} \mathrm{C}$.

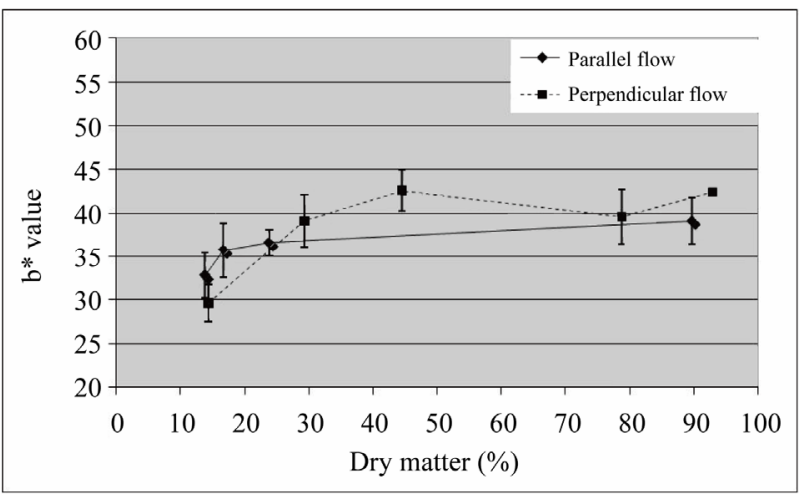

Figure 7. b* values of coated 'Starking' apple cubes dried with parallel airflow or perpendicular airflow at $40^{\circ} \mathrm{C}$.

oxidase activity of 'Starking' apple cubes. In order to prevent coated samples from browning, a thermal treatment of the whole apple is required before drying. Apples dipped in water at $60^{\circ} \mathrm{C}$ for 10 minutes, cut into cubes, coated and dried by perpendicular airflow at $40^{\circ} \mathrm{C}$, presented lower relative activity of polyphenol oxidase and better colour than coated samples that had not been submitted to a thermal treatment. Further studies are required to determine the presence and action/activity of peroxidise and/or other enzymes that could have an important role in browning apple tissue.

\section{Acknowledgements}

C. A. S. Ribeiro acknowledges financial support (BII/ LAB/0016/2008) from Fundação para a Ciência e Tecnologia (FCT) of Portuguese Republic Government. As researchers of the Associate Laboratory CBQF (LA50016), A. M. M. B. Morais and R. M. S. C. Morais acknowledge financial support from programme Plurianual of FCT.

\section{REFERENCES}

[1] C. Y. Lee, "Enzymatic Browning Reaction,” In: F. J. Francis, Ed., Encyclopedia of Food Science and Technology (2 ${ }^{\text {nd }}$ Edition), Wiley, New York, 1999, pp. 494515.

[2] J. Whiteker, "Principles of Enzymology for the Food Sciences,” M. Dekker, New York, 1972, pp. 571-577.

[3] G. I. Olivas and G. V. Barbosa-Cánovas, "Edible coatings for Fresh-Cut Fruits," Critical Reviews of Food Science and Nutrition, Vol. 45, No. 7-8, 2005, pp. 657670. doi:10.1080/10408690490911837

[4] S. L. S. Bico, M. F. J. Raposo, R. M. S. C. Morais and A. M. M. B. Morais, "Combined Effects of Chemical Dip and/or Carrageenan Coating and/or Controlled Atmosphere on Quality of Fresh-Cut Banana," Food Control, Vol. 20, No. 5, 2009, pp. 508-514. 
doi:10.1016/j.foodcont.2008.07.017

[5] J. Y. Lee, H. J. Park, C. Y. Lee and W. Y. Choi, "Extending Shelf-Life of Minimally Processed Apples with Edible Coatings and Antibrowning Agents," Lebensmittel-Wissenschaft and Technologie, Vol. 36, No. 3, 2003, pp. 323-329.

[6] S. L. S. Bico, M. F. J. Raposo, R. M. S. C. Morais and A. M. M. B. Morais, "Chemical Dips and Edible Coatings to Retard Softening and Browning of Fresh-Cut Banana,” International Journal of Postharvest Technology and Innovation, Vol. 2, No. 1, 2010, pp. 13-24.

[7] M. A. Rojas-Graü, M. S. Tapia and O. Martín-Belloso, "Using Polysaccharide-Based Edible Coatings to Maintain Quality of Fresh-Cut Fuji apples,” LWT-Food Science and Technology, Vol. 41, No. 1, 2008, pp. 139-147. doi:10.1016/j.lwt.2007.01.009

[8] M. M. Khin, W. Zhou and C. O. Perera, "Impact of Process Conditions and Coatings on the Dehydration Efficiency and Cellular Structure of Apple Tissue during Osmotic Dehydration," Journal of Food Engineering, Vol. 79, No. 3, 2007, pp. 817-827. doi:10.1016/j.jfoodeng.2006.02.046

[9] G. I. Olivas, D. S. Mattinson and G. V. Barbosa-Cánovas, "Alginate Coatings for Preservation of Minimally Processed 'Gala' Apples,” Postharvest Biology and Technology, Vol. 45, No. 1, 2007, pp. 89-96. doi:10.1016/j.postharvbio.2006.11.018

[10] D. J. McHugh, “Alginate,” In: D. J. McHugh, Ed., A Guide to the Seaweed Industry, Fisheries and Aquaculture Department, 2003, pp. 39-50.

[11] M. Sen, "Effects of Molecular Weight and Ratio of Guluronic Acid to Mannuronic Acid on the Antioxidant Properties of Sodium Alginate Fractions Prepared by Radiation-Induced Degradation,” Applied Radiation and Isotopes, Vol. 69, No. 1, 2011, pp.126-129. doi:10.1016/j.apradiso.2010.08.017

[12] H. Trommer and R. H. H. Neubert, "The Examination of Polysaccharides as Potential Antioxidative Compounds for Topical Administration Using a Lipid Model System,” International Journal of Pharmaceutics, Vol. 298, No. 1, 2005, pp. 153-163. doi:10.1016/j.ijpharm.2005.04.024.

[13] M. A. Rojas-Graü, M. S. Tapia, F. J. Rodriguez, A. J. Carmona and O. Martín-Belloso, "Alginate and Gellanbased Edible Coatings as Carriers of Antibrowning Agents Applied on Fresh-Cut 'Fuji' Apples,' Food Hydrocolloids, Vol. 21, No. 1, 2007, pp. 118-127. doi:10.1016/j.foodhyd.2006.03.001

[14] J. D. Ponting, R. Jackson and G. Walters, "Refrigerated Apple Slices: Effects of $\mathrm{pH}$, Sulfites and Calcium on Texture,” Journal of Food Science, Vol. 36, No. 2, 1971, pp. 449-450. doi:10.1111/j.1365-2621.1971.tb04059.x

[15] A. Lenart and D. Piotrowski, "Drying Characteristics of Osmotically Dehydrated Fruits Coated with Semipermeable Edible Films," Drying Technology, Vol. 19, No. 5, 2001, pp. 849-877. doi:10.1081/DRT-100103772
[16] M. M. Khin, W. Zhou and C. O.Perera, "A Study of the Mass Transfer in Osmotic Dehydration of Coated Potato Cubes,” Journal of Food Engineering, Vol. 77, No. 1, 2006, pp.84-95. doi:10.1016/j.jfoodeng.2005.06.050

[17] Commission Internationale de L'Eclairage (CIE), "Recommendations on Uniform Colour Spaces, ColourDifference Equations, Psychometric Colour Terms,” CIE, Paris, 1978.

[18] A. M. C. N. Rocha and A. M. M. B. Morais, "Polyphenoloxidase Activity and Total Phenolic Content as Related to Browning of Minimally Processed 'Jonagored' Apple,” Journal of the Science of Food and Agriculture, Vol. 82, No. 1, 2001, pp. 120-126. doi:10.1002/jsfa.1006

[19] E. Cantos, J. A. Tudela, M. I. Gil and J. C. Espín, "Phenolic Compounds and Related Enzymes are not Rate- Limiting in Browning Development of Fresh-Cut Potatoes,” Journal of Agriculture and Food Chemistry, Vol. 50, No. 10, 2002, pp. 3015-3023. doi:10.1021/jf0116350

[20] A. M. C. N. Rocha, C. Mota and A. M. M. B. Morais, "Efeito de Armazenamento sob Vácuo na Actividade da PPO e nos Compostos Fenólicos da Cenoura Descascada (cv. Nantes)," Proceedings of $7^{\circ}$ Encontro de Química de Alimentos, Viseu, 13-16 April 2005, in CDROM.

[21] M. Karel, "Water Activity and Food Preservation,” In: M. Karel, O. R. Fennema and D. B. Lund, Eds., Principles of Food Science (Part II), Marcel Dekker, New York, 1975, pp. 237-263.

[22] M. P. Cano, M. G. Lobo, B. de Ancos and M. A. M. Galeazzi, "Polyphenoloxidase from Spanish Hermaphrodite and Female Papaya Fruits (Carica papaya cv. Sunrise, Solo Group)," Journal of Agriculture and Food Chemistry, Vol. 44, No. 10, 1996, pp. 3075-3079. doi:10.1021/jf960119k

[23] D. M. N. Eidhin, E. Murphy and D. O’Beirne, "Polyphenol oxidase from Apple (Malusdomestica borkh. cv. Bramley's Seedling): Purification Strategies and Characterization," Journal of Food Science, Vol. 71, No. 1, 2006, pp. C51-C58. doi:10.1111/j.1365-2621.2006.tb12388.x

[24] Y. Jiang, "Properties of Litchi Polyphenoloxidase,” Acta Horticulturae (ISHS), Vol. 558, 2001, pp. 367- 373.

[25] G. P. Mizobutsi, F. L. Finger, R. A. Ribeiro, R. Puschmann, L. L. M. Neves, and W. F. da Mota, "Effect of pH and Temperature on Peroxidase and Polyphenol-Oxidase Activities of Litchi Pericarp," Science and Agriculture, Vol. 67, No. 2, 2010, pp.213-217.

[26] Z. Emam-Djomeh, J. Dehghannya and R. SotudehGharabagh, "Assessment of Osmotic Process in Combination with Coating on Effective Diffusivities during Drying of Apple Slices,” Drying Technology, Vol. 24, No. 9, 2006, pp. 1159-1164. doi:10.1080/07373930600778437

[27] I. Damaldi, G. Rapeanu, A. van Loey, C. Smout and M. 
Hendrickx, "Characterization and Inactivation by Thermal and Pressure Processing of Strawberry (Fragaria ananassa) Polyphenol Oxidase: A Kinetic Study," Journal of Food Biochemistry, Vol. 30, No. 1, 2006, pp. 56-76. doi:10.1111/j.1745-4514.2005.00045.x
[28] D. M. Kim, N. L. Smith and C. Y. Lee, "Effect of Heat Treatment on Firmness of Apples and Apple slices," Journal of Food Processing and Preservation, Vol. 18, No. 1, 1994, pp. 1-8.

doi:10.1111/j.1745-4549.1994.tb00237.x 